\section{Resin-coated Fertilizers Affect Postproduction Growth, but Not Flowering, of Potted Alstroemeria}

\author{
Alessandro Chiari ${ }^{1}$, George C. Elliott ${ }^{2}$, and Mark P. Bridgen \\ University of Connecticut, Department of Plant Science, U-67, Storrs, \\ CT 06269-4076
}

Additional index words. Lily-of-the-Incas, Inca lily, Peruvian lily, controlled-release fertilizer, postproduction performance

\begin{abstract}
Seven resin-coated fertilizers (RCF) (Osmocote 19-6-12, 18-6-12, 14-14-14, 1313-13, and 19-6-12, and Polyon 19-6-12, 17-17-17, and 13.5-13.5-13.5) were applied to marketable potted Alstroemeria hybrid FL101 plants to determine their effects on postproduction flowering and growth. The nonfertilized control produced the greatest number of floral stems, total florets, and mean number of florets per stem, but these plants were extremely chlorotic and spindly, and had the lowest fresh weight and number of vegetative stems. In a subsequent experiment, plants were fertilized with low, medium, and high concentrations of either Osmocote 19-6-12 or Sierra HighN 24-4-8. Nonfertilized controls were again chlorotic and spindly, but produced as many florets as fertilized plants. Plants fertilized with Osmocote 19-6-12 had greater fresh weight and more vegetative stems, but fewer total florets than those fertilized with Sierra HighN 24-4-8. We concluded that potted Alstroemeria do not need fertilizer for continued flowering, and fertilization favors production of vegetative stems relative to flowering stems. However, application of RCF to marketable plants prevents chlorosis, increases fresh weight, and, if low to moderate rates of formulations with $\mathrm{N}-\mathrm{P}$ ratios of at least 6:1 are applied, does not inhibit flowering.
\end{abstract}

Alstroemeria hybrids are usually grown for cut flowers, but can also be produced as potted flowering plants (Bridgen, 1997). While the effects of environmental factors on cutflower production of Alstroemeria have been investigated, there are no published reports on the effects of postproduction fertilization on the performance of flowering potted Alstroemeria. Argo and Biernbaum (1993a) reported that consumers expect flowering hanging baskets to last all summer. This expectation could reasonably be extended to potted Alstroemeria.

For cut-flower production of Alstroemeria, fertilizer with $\mathrm{N}-\mathrm{K}$ ratios ranging from 1:0.8 to $1: 1.2$ are recommended (Bik and van den Berg, 1981). In Italy, greenhouse-grown Alstroemeria is fertilized with a $\mathrm{N}-\mathrm{P}-\mathrm{K}$ ratio of 2:0.4:0.8 during vegetative growth; this ratio is changed to $2: 0.4: 1.7$ as the crop approaches flowering (Cocozza Talia and $\mathrm{Fa}-$

\footnotetext{
Received for publication 2 Jan. 1998. Accepted for publication 19 Oct. 1998. Storrs Agricultural Experiment Station publication No. 1837. Use of trade names in this publication does not imply endorsement of products used in this research nor is criticism implied of similar products not named. The cost of publishing this paper was defrayed in part by the payment of page charges. Under postal regulations, this paper therefore must be hereby marked advertisement solely to indicate this fact.

${ }^{1}$ Current address: Brooklyn Botanic Garden, Brooklyn, NY 11225-1099.
}

${ }^{2}$ To whom reprint requests should be addressed. rina, 1991). In the United States, Alstroemeria plants may be fertilized with as much as 600 $\mathrm{mg} \cdot \mathrm{L}^{-1}$ of $\mathrm{N}_{\text {as }} \mathrm{KNO}_{3}$ twice weekly (Healy and Wilkins, 1991). Flower production increases and flower initiation is hastened when $\mathrm{N}$ is applied at $400 \mathrm{mg} \cdot \mathrm{L}^{-1}$ every 7 to $10 \mathrm{~d}$ (Smith et al., 1998).

Potted Alstroemeria can be produced using the cut-flower crop fertilizer recommendations. Madson (1995), working with potted Alstroemeria hybrid FL-101, showed that increasing $\mathrm{P}$ fertilization up to $74 \mathrm{mg} \cdot \mathrm{L}^{-1}$, applied at every irrigation during the production phase, increased subsequent yield of flower stems and total number of florets per stem in plants that received no further fertilization. She also observed that the medium was depleted of $\mathrm{N}, \mathrm{P}$, and $\mathrm{K}$ at the end of the flowering period, and suggested that the use of resin-coated fertilizers (RCF) during the postproduction flowering season might benefit potted

Argo and Biernbaum (1993b) investigated the use of RCF to improve the garden performance of flowering hanging baskets. Applying an RCF as a topdressing to Impatiens walleriana Hook $\mathrm{f}$. in $25-\mathrm{cm}$ baskets prior to placing them in an outdoor environment allowed the plants to flower until the end of August, while the production of blooms decreased rapidly in nonfertilized plants. Adequate fertilization of flowering potted plants throughout their postproduction life requires high rates of RCF incorporated in the medium prior to planting, but high preplant incorporation rates of RCF are injurious to salt-sensitive plants such as New Guinea impatiens (ImpaAlstroemeria. tiens hawkeri Bull.) and tuberous begonias (Begonia tuberhybrida Voss.) (Argo and Biernbaum, 1993b). Since Alstroemeria is sensitive to high salt levels (Bridgen, 1992; van der Krogt, 1991) preplant incorporation of RCF at levels adequate to sustain postproduction growth would probably be harmful.

The objective of our research was to determine the effect of RCF, applied as a topdressing to marketable Alstroemeria potted plants, on postproduction flowering and growth. In the first experiment we compared the effect of fertilizers having different ratios of $\mathrm{N}-\mathrm{P}-\mathrm{K}$ and release periods; in a subsequent experiment we compared the effect of three different concentrations of two fertilizers differing in $\mathrm{N}-\mathrm{P}-\mathrm{K}$ ratio and release period. These trials were intended to provide information to producers of potted Alstroemeria about the efficacy of RCF applications to marketable potted plants, and to provide a basis for further investigation of the effects of fertilization on growth and flowering in Alstroemeria.

\section{Materials and Methods}

Effect of $N-P-K$ ratio and release time (Expt. 1). Divisions consisting of storage roots and rhizomes of the Univ. of Connecticut Alstroemeria hybrid FL101 were planted in 6.6-L pots using Par-gro Peatwool potting medium (Partex Industries, Phenix City, Ala.) in Jan. 1995. Plants were placed in a greenhouse with heating setpoint at $10^{\circ} \mathrm{C}$ and fan ventilation setpoint at $18^{\circ} \mathrm{C}$. Plants were fertilized every 2 weeks until Apr. 1995, alternating $17 \mathrm{~N}-1 \mathrm{P}-20 \mathrm{~K}$ and $15 \mathrm{~N}-0 \mathrm{P}-14 \mathrm{~K}$ formulations with a $\mathrm{N}$ concentration of $300 \mathrm{mg} \cdot \mathrm{L}^{-1}$. When plants started flowering at the end of May, 48 pots were chosen for uniformity and randomly grouped into six blocks of eight pots each. Eight RCF treatments were applied as topdressings: $28.9 \mathrm{~g} / \mathrm{pot}$ of $19 \mathrm{~N}-2.6 \mathrm{P}-10 \mathrm{~K}$ (Osmocote 19-6-12,3-4 months release), 38.2 $\mathrm{g} /$ pot of $18 \mathrm{~N}-2.6 \mathrm{P}-10 \mathrm{~K}$ (Osmocote 18-6-12, 8-9 months release), $39.3 \mathrm{~g} /$ pot of $14 \mathrm{~N}-6.1 \mathrm{P}-$ 11.6K (Osmocote 14-14-14, 3-4 months release), $52.9 \mathrm{~g} /$ pot of $13 \mathrm{~N}-5.7 \mathrm{P}-10.8 \mathrm{~K}$ (Osmocote 13-13-13, 8-9 months release), $28.9 \mathrm{~g} /$ pot of $19 \mathrm{~N}-2.6 \mathrm{P}-10 \mathrm{~K}$ (Polyon 19-6$12,3-4$ months release), $32.4 \mathrm{~g} /$ pot of $17 \mathrm{~N}-$ 7.4P-14.1K (Polyon 17-17-17, 3 months release), $50.9 \mathrm{~g} / \mathrm{pot}$ of $13.5 \mathrm{~N}-5.9 \mathrm{P}-11.2 \mathrm{~K}$ (Polyon 13.5-13.5-13.5, 8-9 months release), and the nonfertilized control. Osmocote formulations were produced by The Scotts Co., Marysville, Ohio, and Polyon formulations by Pursell Industries, Sylacauga, Ala. Treatments provided $\mathrm{N}$ per unit volume of growing medium ranging between 1.0 and $1.25 \mathrm{~kg} \cdot \mathrm{m}^{-3}$, and constituted "medium" application rates according to manufacturers' suggestions. The numbers of stems produced and the numbers of florets per inflorescence were counted from 9 June to 12 Sept. 1995. At the end of the experiment, the entire aerial portion of the plant was weighed and vegetative stems were counted.

Effect of RCF rates (Expt. 2). Alstroemeria divisions were potted in Mar. 1996 and grown 
under the same environmental setpoints as in Expt. 1. Plants began flowering in mid-May, when 35 pots were chosen for their uniformity and grouped into five blocks of seven pots each. Seven treatments were applied as topdressings: $19 \mathrm{~N}-2.6 \mathrm{P}-10 \mathrm{~K}$ (Osmocote 196-12) at low (11.6 g/pot), medium (23.2 g/ pot), and high (46.3 g/pot) concentrations; 24N-1.7P-6.6K (Sierra HighN 24-4-8, 8-9 months release, The Scotts Co.) at low $(9.2 \mathrm{~g} /$ pot), medium (18.3 g/pot), and high (36.7 g/ pot) concentrations, and the nonfertilized control. Total $\mathrm{N}$ per unit volume for the low, medium, and high concentrations were 0.4 , 0.8 and $1.6 \mathrm{~kg} \cdot \mathrm{m}^{-3}$, respectively. The number of stems produced and number of florets per inflorescence were counted from 30 May to 11 Oct. 1996. At the end of the experiment, the entire aerial portion of the plant was weighed and vegetative stems were counted. Both experiments were analyzed as randomized complete-block designs. Analysis of variance was performed with the GLM procedure of the SAS 6.03 statistical program (SAS Institute, Cary, N.C).

\section{Results and Discussion}

In comparison with several RCF formulations (Expt. 1), the nonfertilized control produced the greatest number of florets but the least fresh weight and fewest vegetative stems (Table 1). Application of Osmocote 19-6-12, Osmocote 18-6-12, and Polyon 19-6-12 did not affect the total number of floral stems produced. Only Osmocote 18-6-12 and Polyon 13.5-13.5-13.5 produced fewer florets per stem than the control treatment. Linear contrast showed that fertilizers with a net N-P-K ratio of $\approx 9: 1.3: 5\left(\mathrm{~N}-\mathrm{P}_{2} \mathrm{O}_{5}-\mathrm{K}_{2} \mathrm{O}=1: 1: 1\right)$ produced significantly fewer floral stems than fertilizers with a net $\mathrm{N}-\mathrm{P}-\mathrm{K}$ ratio of $\approx 7: 3: 6$ $\left(\mathrm{N}-\mathrm{P}_{2} \mathrm{O}_{5}-\mathrm{K}_{2} \mathrm{O}=3: 1: 2\right)$. Plants that were not fertilized were extremely chlorotic and spindly while all the plants treated with fertilizer were green and full.

Fertilizers with lower $\mathrm{P}$ and $\mathrm{K}$, such as Osmocote 19-6-12, produced a yield of total floral stems and florets statistically equal to the nonfertilized control, but with significantly greater fresh weight and no chlorosis. Therefore, in the subsequent experiment we compared this fertilizer with HighN 24-4-8, a fertilizer containing even lower concentrations of $\mathrm{P}$ and $\mathrm{K}$. We also tested the effects of different rates of fertilizer, corresponding to low, medium, and high rates based on the manufacturer's label recommendations. The yield in total number of floral stems ranged from 10.6 to 16.4 , but differences were nonsignificant. However, contrasts showed that plants fertilized with Sierra HighN 24-4-8 yielded more total florets than those fertilized with Osmocote 19-6-12, particularly at the low rate. Plants fertilized with Osmocote 196-12 were heavier and had more vegetative stems than those fertilized with Sierra HighN 24-4-8 (Table 2). Fresh weight and number of vegetative stems increased with increasing rate of fertilization, with the highest response to a high rate of Osmocote 19-6-2. At the end

Table 1. Effects of several resin-coated fertilizers on the growth and flowering of potted Alstroemeria. Expt. 1.

\begin{tabular}{|c|c|c|c|c|c|}
\hline \multirow[b]{2}{*}{ Fertilizer } & \multirow{2}{*}{$\begin{array}{c}\text { Fresh } \\
\text { wt } \\
(\mathrm{g})\end{array}$} & \multirow{2}{*}{$\begin{array}{c}\text { No. } \\
\text { floral } \\
\text { stems }\end{array}$} & \multicolumn{2}{|c|}{ No. florets } & \multirow{2}{*}{$\begin{array}{c}\text { Mean no. } \\
\text { vegetative } \\
\text { stems }\end{array}$} \\
\hline & & & Total & $\overline{\text { No./stem }}$ & \\
\hline \multicolumn{6}{|l|}{ Osmocote } \\
\hline 14-14-14 & $1241 \mathrm{a}^{\mathrm{z}}$ & $24 \mathrm{bc}$ & $142 \mathrm{bc}$ & $6.3 \mathrm{ab}$ & $59 \mathrm{ab}$ \\
\hline $13-13-13$ & $1156 \mathrm{a}$ & $25 \mathrm{bc}$ & $150 \mathrm{bc}$ & $6.3 \mathrm{ab}$ & $54 \mathrm{~b}$ \\
\hline $19-6-12$ & $1171 \mathrm{a}$ & $30 \mathrm{ab}$ & $159 \mathrm{~b}$ & $6.1 \mathrm{a}-\mathrm{c}$ & $58 \mathrm{ab}$ \\
\hline $18-6-12$ & $1177 \mathrm{a}$ & $26 a-c$ & $138 \mathrm{bc}$ & $5.4 \mathrm{c}$ & $61 \mathrm{ab}$ \\
\hline \multicolumn{6}{|l|}{ Polyon } \\
\hline $17-17-17$ & $1119 \mathrm{a}$ & $21 \mathrm{c}$ & $118 \mathrm{c}$ & $6.3 \mathrm{a}-\mathrm{c}$ & $65 \mathrm{a}$ \\
\hline $13.5-13.5-13.5$ & $971 \mathrm{~b}$ & $25 \mathrm{bc}$ & $127 \mathrm{bc}$ & $5.6 \mathrm{bc}$ & $64 \mathrm{ab}$ \\
\hline $19-6-12$ & $1149 \mathrm{a}$ & $26 a-c$ & $137 \mathrm{bc}$ & $5.8 \mathrm{a}-\mathrm{c}$ & $56 \mathrm{ab}$ \\
\hline None & $457 \mathrm{c}$ & $32 \mathrm{a}$ & $196 \mathrm{a}$ & $6.5 \mathrm{a}$ & $30 \mathrm{c}$ \\
\hline \multicolumn{6}{|l|}{ Contrasts } \\
\hline $1-1-1$ vs. $3-1-2$ & NS & * & $*$ & NS & NS \\
\hline $3-4$ vs. $8-9$ months & NS & NS & NS & NS & NS \\
\hline
\end{tabular}

${ }^{2}$ Mean separation within columns by Duncan's multiple range test, at $P \leq 0.05$.

Ns, * Nonsignificant or significant at $P \leq 0.05$, respectively.

Table 2. Effect of three different concentrations of each of two resin-coated fertilizers on the growth and flowering of potted Alstroemeria. Expt. 2.

\begin{tabular}{|c|c|c|c|c|}
\hline & & $\begin{array}{c}\text { Fresh } \\
\text { wt }\end{array}$ & Florets & $\begin{array}{l}\text { Vegetative } \\
\text { stems }\end{array}$ \\
\hline Fertilizer & Rate & (g/plant) & \multicolumn{2}{|c|}{ No./plant } \\
\hline \multicolumn{5}{|l|}{$\overline{\text { Osmocote }}$} \\
\hline $19-6-12$ & Low & $491 \mathrm{~d}^{\mathrm{z}}$ & 82 & $25 \mathrm{~cd}$ \\
\hline $19-6-12$ & Medium & $825 \mathrm{ab}$ & 92 & $44 \mathrm{ab}$ \\
\hline $19-6-12$ & High & $944 \mathrm{a}$ & 75 & $48 \mathrm{a}$ \\
\hline \multicolumn{5}{|l|}{ Sierra HighN } \\
\hline $24-4-8$ & Low & $275 \mathrm{e}$ & 127 & $14 \mathrm{de}$ \\
\hline $24-4-8$ & Medium & $576 \mathrm{~cd}$ & 100 & $31 \mathrm{bc}$ \\
\hline $24-4-8$ & High & $667 \mathrm{bc}$ & 98 & $40 \mathrm{ab}$ \\
\hline None & & $31 \mathrm{f}$ & 66 & $2 \mathrm{e}$ \\
\hline \multicolumn{5}{|l|}{ Contrasts } \\
\hline None vs. fertilizer & & $* *$ & NS & $* *$ \\
\hline Low vs. medium vs. high & & ** & NS & ** \\
\hline Within low & & $*$ & $*$ & NS \\
\hline Within medium & & ** & NS & * \\
\hline Within high & & $* *$ & NS & NS \\
\hline $19-6-12$ vs. $24-4-8$ & & $* *$ & $*$ & $* *$ \\
\hline Within $19-6-12$ & & $* *$ & NS & $* *$ \\
\hline Within $24-4-8$ & & ** & NS & ** \\
\hline
\end{tabular}

${ }^{\mathrm{x}}$ Mean separation within columns by Duncan's multiple range test, at $P \leq 0.05$.

ws, ****Nonsignificant or significant at $P \leq 0.05$ or 0.01 , respectively.

of the experiment, the nonfertilized plants were very small, chlorotic, and had few stems, but were still flowering. Plants that received the low rate of either fertilizer exhibited some chlorosis on the lower leaves. Plants were smaller and produced fewer flowers in the second experiment than in the first, because the production phase was shorter and the plants were smaller at the time of RCF application.

Argo andBiernbaum (1993b) demonstrated that topdressing with medium to high rates of RCF supported continued bloom of Impatiens walleriana for at least 12 weeks. Alstroemeria plants in the second experiment continued flowering for 16 weeks and plants were still producing flowering stems at the final harvest, without any fertilizer.

Both experiments demonstrated that marketable potted Alstroemeria can flower for several months without the use of any fertilizer. This is in striking contrast to the results of Argo and Biernbaum (1993b), who observed a rapid decrease in flowering of unfertilized
Impatiens walleriana. We suggest that this reflects the remobilization of nutrients from Alstroemeria storage roots to support flowering. However, nonfertilized plants were much smaller than fertilized plants and extremely chlorotic, indicating inadequate nutrition in the absence of fertilization. Unfertilized plants weighed less and produced fewer vegetative stems, but not fewer floral stems, demonstrating that mineral nutrition strongly influences the partitioning of assimilates into reproductive vs. vegetative growth. Minimizing the number of vegetative stems while maintaining high production of flowering stems would be desirableforAlstroemeria, especially those grown for cut flowers, because excessive vegetative stems should be removed from the plants to increase light intensity in the interior of the plant (Bridgen, 1997; Healy and Wilkins, 1991).

In the first experiment, plants fertilized with RCF with an N-P-K ratio of $\approx 9: 1.3: 5$ produced more flowers than those fertilized with a ratio of $\approx 7: 3: 6$. In the second experi- 
ment, the RCF formulation with the net N-PK ratio 12:0.85:3.3 produced a greater number of florets, but plants had a lower fresh weight than the 9:1.3:5 formulation. Further research will be required to fully elucidate the effect of $\mathrm{N}-\mathrm{P}-\mathrm{K}$ ratios on flowering in Alstroemeria. The release time of the RCF had no effect when comparing similar $\mathrm{N}-\mathrm{P}-\mathrm{K}$ formulations, as was observed by Argo and Biernbaum (1993b) for the postproduction performance of Impatiens walleriana.

The results of this study show that fertilization is not required for postproduction flowering of potted Alstroemeria plants. However, topdressing marketable plants with RCF prevents leaf chlorosis and increases vegetative growth. Based on the results of both experiments, a medium rate of RCF, supplying $\mathrm{N}$ at $\approx 0.8$ to $1.2 \mathrm{~kg} \cdot \mathrm{m}^{-3}$, is adequate.

\section{Literature Cited}

Argo, W.R. and J.A. Biernbaum. 1993a. Factors affecting garden performance of flowering plants in hanging baskets. Bedding Plants Foundation Res. Rpt. F-061.

Argo, W.R. and J.A. Biernbaum. 1993b. Factors affecting garden performance of flowering plants in hanging baskets. Bedding Plants Foundation Res. Rept. F-061A.

Bik, R.A. and T.J.M. van den Berg. 1981. Nitrogen and potassium fertilization of the Alstroemeria cultivars 'Orchid' and 'Carmen' grown on peat. Acta Hort. 126:287-292.

Bridgen, M.P. 1992. Alstroemeria, p. 201-209. In: A.A. DeHertogh and M. LeNard (eds.). The physiology of flower bulbs-A comprehensive treatise on the physiology and utilization of ornamental flowering bulbous and tuberous plants. Elsevier, New York.

Bridgen, M.P. 1997. Alstroemeria, p. 341-348. In:
Vic Ball (ed.). The Ball RedBook, 16th ed. Ball Publ., W. Chicago, Ill.

Cocozza Talia, M.A. and E. Farina. 1991. La coltivazione dell'Alstroemeria in Italia: realta' e prospettive, p. 39-48. In:E. Farina (ed.). Giornata di studio su Alstroemeria. Inst. Sper. per la Floricoltura, San Remo, Italy.

Healy, W. and H.F. Wilkins 1991. Alstroemeria, p. 311-316. In: Vic Ball (ed.). The Ball Redbook, 15th ed. Ball Publ., W. Chicago, Ill.

Madson, L. 1995. Phosphorus fertilization of Alstroemeria. MS Thesis, Dept. Plant Sci., Univ. of Connecticut.

Smith, M.A., G.C. Elliott, and M.P. Bridgen. 1998. Calcium and nitrogen fertilization of greenhouse-grown Alstroemeria. HortScience 33:5559.

van der Krogt, T. 1991. L'Alstroemeria in Olanda, p. 33-38. In: E. Farina (ed.). Giornata di studio su Alstroemeria. Inst. Sper. per la Floricoltura, San Remo, Italy. 